\title{
Innovations that changed Mammalogy: museum study skins
}

\author{
Robert M. Timm, ${ }^{* \bullet}$ Suzanne B. McLaren, and Hugh H. Genoways \\ Natural History Museum and Department of Ecology \& Evolutionary Biology, University of Kansas, Lawrence, KS 66045, \\ USA (RMT) \\ Section of Mammals, Edward O'Neil Research Center, Carnegie Museum of Natural History, Pittsburgh, PA 15206, USA (SBM) \\ University of Nebraska State Museum, University of Nebraska-Lincoln, Lincoln, NE 68588, USA (HHG) \\ *Correspondent: btimm@ku.edu
}

Scientific specimens, the cornerstone of our discipline, have a rich and colorful history. Yet perhaps the most classic study in evolutionary biology based on specimens-Charles Darwin's study of the finches of the Galapagos Islands-almost wasn't possible despite Darwin collecting a number of specimens. Darwin accompanied Vice-Admiral Robert FitzRoy, captain of the British warship H. M. S. Beagle, on the 5-year round-theworld voyage as the ship naturalist (1831-1836). After returning to England, Darwin and John Gould, the famous English ornithologist, were handicapped in using Darwin's specimens to unravel the complexities of the bill sizes and shapes and species diversity of Galapagos finches because Darwin had neglected to label the individual islands from which his specimens were collected. To unravel the evolution of the birds known as Darwin's finches, Darwin and Gould relied on the specimens of Robert FitzRoy's and Darwin's servant, Syms Covington, because they had been labeled by island. Attributing the holotypes of Darwin's finches to the specific island collected remains problematic to this day (Sulloway 1982). Darwin's failure to label his bird specimens individually was not atypical for the time.

For guidance in preserving natural history specimens during his 5-year voyage on the Beagle, Darwin had a copy of William Swainson's (1822) The naturalist's guide for collecting and preserving all subjects of natural history... Therein the collector is instructed in the preparation of mammals that after removing the skull from the skin to, "removed all flesh ... wash the bones with arsenated soap ... the skull ... may then be filled with cotton ..." and reinserted in the skin "to give the head that plump and natural appearance which it first possessed" (Swainson 1822:13-14). This collecting and preparation guide was one of the standard references for decades because until the mid-1800s, the customary preparation for small mammals either was fluid-preserved or skin with skull reinserted. Swainson's guide (1822:33) indicated that "preservation in spirits is always practicable." Mid-sized and larger mammals generally were prepared as taxidermy mounts.
In 1831, the first specimen preparation guides published in the United States both appeared. Titian Ramsay Peale (1831) working for his father's-Charles Willson Peale—-proprietary Philadelphia Museum almost certainly authored and illustrated the first manual for preparation of natural history objects by an American. His techniques for preparation of mammals do not differ radically from those of earlier authors, but there are some interesting ideas. Mammals were to be prepared to the point of being mounted in the field, but would be transported to the museum for the final preparation. Skulls were to be left attached to the skin, so they could be included in the final museum specimens except for "Large quadrupeds ... the skull and legs may be removed, leaving only the hoofs attached to the skin; the skull, however, must in all cases be saved" (Peale 1831:12). Peale's technique for the initial incision for skinning mammals the size of a fox and smaller was unique, recommending “... the best place to make the incision ... is from about the middle of the back to the insertion of the tail ..." (Peale 1831:11). For larger mammals, he recommended an incision along the middle of the belly from near the anus to the middle of the lower jaw and perpendicular incisions from the midline down the inside of each leg. The skins were then to be stored in a solution of corrosive sublimate (mercury chloride, $\mathrm{HgCl}_{2}$ ) and spirits (probably spirits of wine, ethyl alcohol at 60-65\%-Timm et al. 2021) in a keg or barrel with wooden hoops because iron hoops would be destroyed by the solution.

An anonymously authored Manual of the Practical Naturalist ... published in Boston in 1831 was aimed at specimens for display as taxidermy mounts and objects for display in a museumlike setting. It includes detailed instructions for the preparation of quadrupeds [= mammals], birds, fishes, and reptiles, as well as display of insects, shells, plants, and minerals. In skinning mammals, the preparator is instructed to remove the skin from the body until, "The hide is now attached to the skull only by the nose, and the tip of the lower-jaw ... take out the brains; remove all of the flesh and muscles from the skull ... give the

(C) The Author(s) 2021. Published by Oxford University Press on behalf of the American Society of Mammalogists, www.mammalogy.org. 
whole hide and skull a good coat of preservative [= arsenic $]$... and your subject is ready to be finally mounted" (Anonymous 1831:114-115). Given that there is no author attribution and that it includes considerable discussion on the history of preparation manuals in Europe going back to the time of Linnaeus, we suspect this Manual is a republication of a European document with the author intentionally omitted.

As the science of mammalogy progressed, the value of having clean skulls to accompany the museum study skin became more and more apparent. Natural selection acting on individual variation within a species became a basic concept of evolutionary biology with the publication of Darwin's Origin of Species in 1859. Thereafter, it became clear that series of specimens were required for scientific studies (Hayes and Jenkins 1997) thereby to better assess differences among species and geographic variation within species. Life-like mounts were impractical due to the time and space required for preparation and storage (Fig. 1). A new approach to skin preparation was needed, especially in mammals, where many species-specific characteristics were associated with the skull and teeth.

In 1846, Spencer Fullerton Baird, who later was to become the Secretary of the Smithsonian Institution, provided the first modern guide for preparation of mammal study specimens while he was a professor at Dickenson College (Carlisle, Pennsylvania; see Baird 1846). Baird's directions are for preparation of birds and quadrupeds as skins, but also include instructions for reptiles and fish, shells, insects, and animals in "other classes of zoology." In addition to his directive that, "The only substance which can be fully relied upon for the preservation of animal skins is arsenic" (Baird 1846:3), he instructs, "As soon as a specimen is collected, a label should be prepared and placed with it, and constantly kept with it in all its transfers" (Baird 1846:10). Upon taking the position of Assistant Secretary of the Smithsonian in charge of the fledgling Natural History Department, he twice updated his "Directions for collecting, preserving, and transporting specimens of natural history" (Baird 1852, 1859). However, a two-page circular he published in 1850, perhaps intended to give to the surgeons of the U.S. Army Medical Corps working in the West and to naval officers, is the first written description outlining his vision of what we now consider the modern scientific specimen of a mammal preserved as a museum study skin. The second page of the circular was a list of desired species. He instructed that:

Skeletons may be roughly prepared by skinning the animal and removing all the viscera, together with as much of the flesh as possible. The bones should then be exposed to the sun or air until completely dried. Previously, however, the brain of large animals should be removed, by separating the skull from the spine, and extracting the contents through the large hole in the back of the head. In case it becomes necessary to disjoint a skeleton, care should be taken to attach a common mark to all the pieces, especially when more than one individual is packed in the same box (Baird 1850).

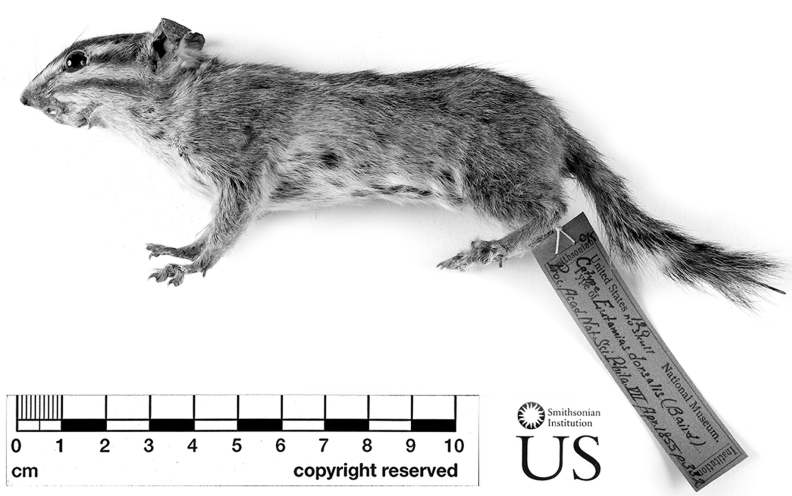

Fig. 1.-Taxidermy mount representing the syntype of Tamias dorsalis Baird, 1855 [now Neotamias dorsalis dorsalis (Baird, 1855)] (USNM 120; Fisher and Ludwig 2012). Specimen collected and prepared in 1851 by J. H. Clark. Skull mounted in skin, note incisors are visible. Specimens prepared in this era had arsenic generously applied to the flesh side of the skin. It should be assumed that arsenic has leached through the skin and is now present externally. Image courtesy of Division of Mammals, National Museum of Natural History, Smithsonian Institution.

Baird's impact on mammalogy and other natural history was immense because from his position at the Smithsonian, he was able to have collectors join expeditions of exploration, he was able to enlist members of the military to supply specimens, and he provided support for the successful collectors to come to the museum to identify and study their collections. His influence was pervasive from 1850 to 1890 .

In 1886, when C. Hart Merriam, Director of Economic Ornithology and Mammalogy, was instructing Vernon Bailey, then a young farm boy in Elk River, Minnesota, he placed particular emphasis on proper preparation of the skull and skins-"Always sew up the belly" - tagging of all parts of a specimen with the same number, and "keep a catalogue of your specimens" (Schmidly 2018:39). Just a few years later these instructions and more found their way into Merriam's (1889) concise and updated guide, reflecting much of Baird's instructions but with more detail, which has been followed to the present day. It lays out the essentials of preparing the standard museum study skin and skull, the external measurements (total length, length of tail, and hindfoot) to be taken at the time of preparation and locality data needed, and how to handle the skull, in a four-page circular. It became the standard, accepted perhaps both for detailed, logical, and illustrated instructions, as well as the force of Merriam's personality and his position then as Chief of the Bureau of Biological Survey. This standard museum study skin and skull preparation became the norm, including rubbing arsenic into the skin, for nearly a century (see Miller 1899; Anderson 1965; Hall 1967, 1981; Nagorsen and Peterson 1980).

Mistakes were made in specimen preparation and many have taken decades to be revealed. Early taxidermy and museum study skins used cotton, newspaper, and tow (coarse flax or broken hemp fibers) for the body, all of which are quite acidic. Skins and all skeletal elements should be left at as close to a pH 7 as possible for long-term stability. Arsenic has long 
been used as an effective insecticide in the preparation of bird and mammal skins, going back to the 1700s taxidermy days in Europe. In Swainson's 1822 manual, preparators were instructed to wash bones and skins in "arsenated soap" and use a preservation powder for which the recipe was "Arsenic and burnt alum, each one pound, and two of tanner's bark, all in powder, mixed, and passed through a sieve; then add half a pound of camphor, and half an ounce of musk; mix well and keep in close tin canisters" (Swainson 1822:64). He does say that the tin containing the mixture should be labeled "poison." This combination no doubt was effective in controlling insect pests.

For decades, field skinning-kits and prep labs contained a small jar of arsenic powder or small crystals and perhaps a small cloth or ball of cotton to dab the powder inside the skin. Arsenic sometimes was mixed with talcum powder to cut its strength. Fingernails that grew out green in color and open sores on the hands were some of the early symptoms of arsenic poisoning. When Bailey reported to Merriam in 1886 that he had suffered arsenic poisoning, Merriam admitted to also having been poisoned himself and offered the following solution: "I find that washing my hands often in cold water, brushing out under my nails with a nail brush, helps immensely when using arsenic. Sal-Ammoniac $\left[\mathrm{NH}_{4} \mathrm{Cl}\right]$ is good to rub on the surface which is inflamed and painful from arsenic" (Schmidly 2018:41). Ingles (1947) in a similar vein advised that hands should be thoroughly cleaned to remove arsenic after completion of specimen preparation. He further states that, "If considerable skinning is to be done, it is well to use a 5 percent iron-dialyzed Merek liquid [= magnesium chloride; in place of arsenic] to prevent the skin from cracking under the finger nails and becoming infected" (Ingles 1947:243).

Caution should be taken today in handling older specimens. The commercially available arsenic test kits are sensitive and accurate, and collections containing older specimens that might be handled for teaching or research should be tested (Marte et al. 2006). In X-ray images, arsenic-treated areas show up as an opaque white shadow.

Arsenic was legally banned from agricultural use in the 1950s, and only gradually fell out of favor in museums. It was used in the preparation of mammal and bird study skins until well into the 1970s. Although never formally banned in museums, with the publication of Rachel Carson's (1962) Silent Spring detailing the hazards of DDT to people and the environment, there was an awakening to the health hazards of a number of chemicals previously used in museums. In both museums and commercial taxidermy, borax powder became more widely used as a safer alternative. The powder, when moistened, forms boric acid, which is effective at killing insects by targeting the stomach and nervous system; however, leaving the skin acidic is not ideal for long-term preservation. Borax is a bleach that can change the color of hair and feathers.

Various mixtures of petroleum-based hydrocarbons have been used as solvents for degreasing skins, especially for fall bats and sciurids that are fat. Soaking skins in benzene, white gas, carbon tetrachloride, and Stoddard's solution (and others), have been used to remove excessive fat (Williams and Hawks 1987), and are effective; however, residues remain and that has complicated efforts to obtain useable DNA from such specimens.

Liquid mercuric chloride was used to treat specimens as an alternative to arsenic. Specimens collected by W. L. Abbott in SE Asia during the late 1890s through the 1910s, and by H. C. Raven in Sulawesi in the 1910s, were treated with this chemical during preparation. Initially, it seemed invisible; however, over time the substance oxidized and became visible where it had been applied on the ears and around the mouth and eyes. Oxidation caused the treated hair to become darker, nearly black, and sometimes metallic-looking but often appearing to be natural coloration (Stavroudis 2003; Makos et al. 2016).

A number of quite volatile and carcinogenic chemicals have been used over the years to fumigate in museum collections to control insect pests, especially dermestid beetles (Coleoptera: Dermestidae, several species) and clothes moths (Lepidoptera: Tineidae, several species). These chemicals included carbon tetrachloride, carbon disulfide (sometimes the two were mixed together), dichlorvos, naphthalene, and paradichlorobenzene (among others), and in addition to posing significant health issues for humans, there can be an impact on the hair and skin of specimens.

Innovations in ecological, morphological, and systematic research in subsequent years triggered innovations in specimen preparation. As the value of ankle and foot bones became more apparent, many preparators began skinning the legs down to that joint or, more recently, to the digits to provide more complete skeletons as well as keeping the foot intact, thus preserving the entire foot. Hafner et al. (1984) suggested preparing skins with a fore- and hindfoot removed and saved as part of the skeleton and the other two feet remaining intact in the skin. Friction ridges of the foot and toe pads have proven quite useful in systematic studies of rodents, especially the families Muridae and Cricetidae. Thus, having both a fore- and hindfoot intact and available on rare specimens is of particular value because pinning through the foot often can destroy the friction ridges. Now that X-ray technology has been improved, X-ray images of Egyptian shrew mummies have provided interesting and unexpected insights into the distribution and systematics of ancient shrews as well as Egyptian religious practices using this nondestructive technology (Woodman et al. 2019).

With the advent of DNA amplification through polymerase chain reaction-PCR amplification of DNA-skin snippets and "crusties" [or osteocrusts, terms that were recently coined referring to scraps of tissue that remain on the skull after preparation] have become of considerable value in molecular systematics. With refinements in extraction procedures, researchers now can use the tissue beneath the keratin of the claw, the tissue beneath the keratin of bovid horns, and the thick toe pads, as well as skin. McDonough et al. (2018) detailed preparation techniques for extracting both mitochondrial and nuclear markers in genomic DNA extracts from dried skins. They found that most historic museum 
study skins yielded good results, although fragment length decreases within the first 30 years after specimen preparation, as well as in tanned and arsenic infused skins. The rabbit viral infection known as Shope Papillomavirus was characterized with whole genome amplification from recent, as well as 100-year old, cottontail rabbit (Sylvilagus) skins, demonstrating that museum study skin collections can be a valuable source for detecting diseases in wildlife through time and characterizing the evolution of diseases and hostviral coevolution (Duch et al. 2015).

Traditional and unanticipated morphological and ecological studies increasingly are being undertaken with museum study skins. Horn keratin from an antelope shot during World War II by an army soldier has been used to establish the regional geochemical baseline in a remote and war-torn Ethiopian desert that is inaccessible to scientists today. Stable isotopes from hair and keratin now are being used to assess distributions across landscapes, foraging and feeding ecology, and environmental contaminants. For example, stable isotopes have been used to better understand the migratory behavior of the poorly known silver-haired bat (Lasionycteris noctivagans) across eastern North America (Fraser et al. 2017). Mercury (Hg) pollution in the environment can now be traced through preserved hair samples (Solgi et al. 2013; Eccles et al. 2019). The fur of Peruvian bats found well downstream from mining operations where $\mathrm{Hg}$ is used in extracting gold contains significant concentrations of $\mathrm{Hg}$. Omnivorous bats had higher concentrations of $\mathrm{Hg}$ than did frugivorous bats, demonstrating that mercury from stream mining operations does enter the terrestrial food web as an environmental pollutant (Moreno-Brush et al. 2018).

The incorporation of biochemical analyses and state-ofthe-art photography has provided interesting insights into the lives of nocturnal mammals (Anich et al. 2021). The amazing and still poorly understood phenomenon of biofluorescence in mammals recently has been discovered in a diverse array of species including the platypus, opossums, bats, flying squirrels, and springhares, using museum study skins.

The preparation and use of the mammal study skin has involved a number of innovations over the last two centuries, and continues today. The science of preparing mammals has gone from the traditional taxidermy mount first developed in Europe for display (Andrei 2020) to research quality specimens that are better preserved and opened the door to future nontraditional and unanticipated studies. The traditional as well as the nontraditional study skin now is of increasing value as we witness dramatic declines and extinction of species and continued large-scale environmental changes. Several new and innovative techniques-sequencing DNA from skins, identifying environmental pollutants, using stable isotopes to better understand movements and diet over time-now allow in-depth study of specimens that were previously unimaginable even a few decades ago. It is critically important that word-of-mouth history on specimen preparations be documented, as well as what can be ascertained from the literature, and associated with individual specimens in collection databases. Knowledge of this history of specimen collection and preparation is increasingly valuable to ecological and evolutionary studies that contribute to innovations in our science, in both education and conservation efforts.

\section{ACKNOWLEDGMENTS}

We thank C. A. Hawks, L. R. Heaney, R. H. Pine, E. A. Rickart, D. J. Schmidly, and N. Woodman for sharing their expertise with us. L. K. Overstreet, Curator of Natural History Rare Books, Smithsonian Libraries, provided insights on historical documents. I. Rochon, Division of Mammals, National Museum of Natural History, Smithsonian Institution, Washington, D.C., generously provided us with the high resolution image of Baird's type to use herein as Fig. 1. We thank T. H. Genoways for assistance in crafting the figure.

\section{Literature Cited}

ANDERSON, R. M. 1965. Methods of collecting and preserving vertebrate animals. 4th ed. (revised). National Museums of Canada Bulletin No. 69, Biological Series No. 18, Ottawa, Ontario.

ANDREI, M. A. 2020. Nature's mirror: how taxidermists shaped America's natural history museums and saved endangered species. University of Chicago Press. Chicago, Illinois.

ANich, P. S., ET AL. 2021. Biofluorescence in the platypus (Ornithorhynchus anatinus). Mammalia 85:179-181.

ANONymous. 1831. Manual of the practical naturalist; or directions for collecting, preparing, and preserving subjects of natural history. Containing instructions and recipes according to the most approved methods for taking and stuffing quadrupeds, birds, fishes, reptiles. Selecting, preserving and arranging insects, minerals, plants, shells, \&c, \&c. Lilly and Wait, and Carter, Hendee and Babcock. Boston, Massachusetts.

BAIRD, S. F. 1846. Hints for preserving objects of natural history. Gitt \& Hinckley. Carlisle, Pennsylvania.

BAIRD, S. F. 1850. General directions for collecting and preserving objects of natural history. Published by the Smithsonian Institution. Washington, D.C. [Printed on a half-sheet of blue letter-paper]

BAIRD, S. F. 1852. Directions for collecting, preserving, and transporting specimens of natural history. Smithsonian Institution. Washington, D.C.

BAIRD, S. F. 1855. Characteristics of some new species of mammals, collected by the U.S. and Mexican Boundary Survey, Major W. H. Emory, U.S.A. Commissioner. Proceedings of the Academy of Natural Sciences of Philadelphia 7:331-333.

BAIRD, S. F. 1859. Directions for collecting, preserving, and transporting specimens of natural history. 3rd ed. Smithsonian Institution. Washington, D.C.

CARson, R. 1962. Silent spring. Houghton Mifflin. New York.

Duch, C. E., R. A. Williams, R. M. Timm, J. Perez-Tris, and L. Benitez. 2015. A century of Shope Papillomavirus in museum rabbit specimens. PLoS ONE 10:e0132172.

Eccles, K. M., E. S. Littlewood, P. J. Thomas, and H. M. Chan. 2019. Distribution of organic and inorganic mercury across the pelts of Canadian river otter (Lontra canadensis). Scientific Reports 9:3237.

Fisher, R. D., And C. A. Ludwig. 2012. Catalog of type specimens of Recent mammals: Rodentia (Sciuromorpha and Castorimorpha) in the National Museum of Natural History, Smithsonian Institution. Smithsonian Contributions to Zoology 640:1-97. 
Fraser, E. E., D. Brooks, and F. J. Longstaffe. 2017. Stable isotope investigation of the migratory behavior of silver-haired bats (Lasionycteris noctivagans) in eastern North America. Journal of Mammalogy 98:1225-1235.

Hafner, D. J., J. C. Hafner, and M. S. Hafner. 1984. Skin-plusskeleton preparation as the standard mammalian museum specimen. Curator 27:141-145.

Hall, E. R. 1981. The mammals of North America. 2nd ed. John Wiley \& Sons. New York.

HaYes, J. P., AND S. H. JENKINS. 1997. Individual variation in mammals. Journal of Mammalogy 78:274-293.

Ingles, L. G. 1947. Mammals of California. Stanford University Press. Stanford, California.

Makos, K., K. K. Schrager, T. Kennedy, C. Hawks, And N. Lockshin. 2016. Arsenic \& old lace: controlling hazardous collection materials. http://www.connectingtocollections.org/arsenic-and-old-lacecontrolling-hazardous-collection-materials. Accessed 22 January 2021.

Marte, F., A. Péquignot, and D. W. Von Endt. 2006. Arsenic in taxidermy collections: history, detection, and management. Collection Forum 21:143-150.

McDonough, M. M., L. D. Parker, N. Rotzel McInerney, M. G. Campana, and J. E. Maldonado. 2018. Performance of commonly requested destructive museum samples for mammalian genomic studies. Journal of Mammalogy 99:789-802.

Merriam, C. H. 1889. Brief directions for the measurement of small mammals and the preparation of museum skins. Division of Economic Ornithology and Mammalogy, U.S. Department of Agriculture. Circular 11:1-4.

Miller, G. S., JR. 1899. Directions for preparing study specimens of small mammals. Bulletin of the U.S. National Museum Part N 39:1-10.

Moreno-Brush, M., A. Portillo, S. D. Brändel, I. Storch, M. TSCHAPKA, AND H. BIESTER. 2018. Mercury concentrations in bats (Chiroptera) from a gold mining area in the Peruvian Amazon. Ecotoxicology 27:45-54.

Nagorsen, D. W., And R. L. Peterson. 1980. Mammal collector's manual. A guide for mammal collector's manual: a guide for collecting, documenting, and preparing mammal specimens for scientific research. Life Sciences Miscellaneous Publications, Royal Ontario Museum. Toronto, Ontario.

Peale, T. R. 1831. Circular of the Philadelphia Museum: containing directions for the preservation and preparation of objects of natural history. James Kay, Jun. and Co. Philadelphia, Pennsylvania. 29 pp.

SchmidLy, D. J. 2018. Vernon Bailey: writings of a field naturalist on the frontier. Texas A\&M Press. College Station.

Solgi, E., S. M. Ghasempouri, and A. E. Sari. 2013. Mercury levels in the river otters (Lutra lutra) of Iran: feasibility of back calculation for trace elements using old stuffed specimens. Ecopersia 1:1-10.

Stavroudis, C. 2003. Mercury, the other heavy metal. Western Association for Art Conservation Newsletter 25:8-11.

SullowAy, F. J. 1982. Darwin and his finches: the evolution of a legend. Journal of the History of Biology 15:1-53.

Swainson, W. 1822. The naturalist's guide for collecting and preserving all subjects of natural history and botany, intended for the use of students and travelers. W. Wood. London, United Kingdom. https://www.biodiversitylibrary.org/bibliography/48633\#/summary. Accessed 19 January 2021.

Timm, R. M., S. B. Mclaren, and H. H. Genoways. 2021. Innovations that changed mammalogy: fluid preparation of specimens. Journal of Mammalogy 102:1-4.

Williams, S. L., and C. A. Hawks. 1987. History of preparation materials used for Recent mammal specimens. Pp. 21-49 in Mammal collection management (H. H. Genoways, C. Jones, and O. L. Rossolimo, eds.). Texas Tech University. Lubbock.

Woodman, N., A. T. Wilken, AND S. IKRAm. 2019. See how they ran: morphological and functional aspects of skeletons from ancient Egyptian shrew mummies (Eulipotyphla: Soricidae: Crocidurinae). Journal of Mammalogy 100:1199-1210.

Submitted 9 March 2021. Accepted 16 March 2021. Associate Editor was Luis A. Ruedas. 